\title{
Designing a model of professional ethics excellence for clinical librarians
}

\author{
Hasan Ashrafi-rizi; Zahra Kazempour; Fatemeh Sheikhshoaei; Zahra Ghazavi, MSc
}

See end of article for authors' affiliations.

\begin{abstract}
Objective: Developing and promoting professional ethics principles for clinical librarians can help the health care system balance the interests of all stakeholders, including clinical librarians, health care professionals, and patients. Therefore, the goal of this study was to design a model of professional ethics excellence for clinical librarians.
\end{abstract}

Methods: The authors conducted a descriptive applied study using literature review and the delphi method. The delphi panel included eleven experts in medical librarianship, library and information sciences, or information sciences and knowledge studies.

Results: After the delphi rounds, five concepts and forty-six components were identified and confirmed to provide a model of professional ethics excellence for clinical librarians. The highest-rated concept was excellence in communication. The highest-rated component was mastery in developing search strategies in information resources and databases.

Conclusions: Identifying and applying principles of professional ethics among clinical librarians can enhance the professionalization of clinical librarians and result in better information services for physicians.

Furthermore, incorporating these principles into the curriculum for health sciences library and information sciences students or into workshops for active clinical librarians can further formalize the profession and practice of evidence-based medicine.

\section{INTRODUCTION}

Professional ethics encompasses a set of ethical principles to which practitioners in a profession agree to adhere and forms an important part of one's professional life [1]. This is especially true for health care providers and medical information-related professionals such as librarians, informationists, and medical information technology professionals, because the disclosure of patient-related information or failure to provide timely and accurate information to health care providers and patients can inflict irreparable damage to the treatment process. The use of valid and up-to-date information in the prevention, diagnosis, treatment, and rehabilitation processes can save lives, reduce medical costs, and improve the quality of health services [2].

In the nineteenth century, Mary W. Plummer, head of the School of Library and Information Science at the Pratt Institute, laid down professional ethics principles and regulations for library practitioners such as physicians, lawyers, clergymen, and university professors. However, professional ethics rules were not formally adopted until the American Library Association (ALA) published the Library Bill of Rights in 1939 and Freedom to Read Statement in 1953 [3, 4]. Since then, international organizations such as the International Federation of Library Associations and Institutions (IFLA) [5] and the Medical Library Association 
(MLA) [6] have developed additional professional codes of ethics for health sciences librarians.

However, there has been no comprehensive attempt to compile professional ethics codes for clinical librarians, who should have their own principles due to their particularly close ties to the health care sector and potential influence on patient care. Clinical librarians are present in treatment teams and wards to help health care professionals search for and evaluate the best evidence and to promote evidence-based medicine (EBM) principles [7]. Finding the best evidence is a valuable skill that clinical librarians possess, because physicians may have difficultly sifting through the large amount of available medical information and distinguishing between credible and unreliable sources. Indeed, clinical librarians have mastery over the design and execution of database search strategies, critical appraisal skills, knowledge of medical terminology, and good communication with health care professionals [7-11].

Clinical librarians who engage in the medical information-seeking process alongside health care professionals must adhere to principles of professional ethics to foster their professional growth and excellence in clinical settings and enhance the quality of care provided to patients. Learning and adhering to professional ethics standards can boost the effectiveness of well-trained and experienced clinical librarians in providing the best evidence for health care professionals to use in making clinical decisions [12]. A review of the literature shows that research on professional ethics in librarianship has mainly examined the practice of professional ethics principles among librarians in general or medical librarians [13-21] or has reformulated these principles for use in different countries and fields [3, 5, 6, 19, 22-24]. In addition, some research points to a slight difference between professional ethics for librarians in general and medical librarians in particular [3,20].

What remains to be addressed, however, is the development and promotion of professional ethics principles for clinical librarians, which could aid in the training of new clinical librarians, enable the evaluation and comparison of professional ethics practices at and among different health care centers, and allow the health care system to better balance the interests of all stakeholders (i.e., clinical librarians, health care professionals, patients).
Therefore, the goal of this study was to design a model of professional ethics excellence for clinical librarians.

\section{METHODS}

The authors performed an applied descriptive study via literature review and the delphi method. The delphi method is a process of obtaining expert group opinions on a topic $[25,26]$ that seeks to align different experts' viewpoints by systematically refining their responses [27]. We selected 11 panel members based on non-probability purposive sampling. Panel members (men, $\mathrm{n}=7$; women, $\mathrm{n}=4$ ) consisted of faculty members in medical librarianship $(\mathrm{n}=4)$, library and information sciences $(n=1)$, or information sciences and knowledge studies $(n=6)$ at 8 different universities (Ahvaz University of Medical Sciences, Allameh Tabataba'i University, Bushehr University of Medical Sciences, Iran University of Medical Sciences, Iranian Research Institute for Information Science \& Technology, Isfahan University of Medical Sciences, Kerman University of Medical Sciences, and Shahid Beheshti University of Medical Sciences) who had a background in education or research in clinical librarianship or professional ethics in the field of medical librarianship. The highest degree of 9 panel members was a doctorate (PhD), whereas 2 had a master's degree. Two panel members were associate professors, 7 were assistant professors, and 2 were lecturers.

For the first delphi round, we prepared a questionnaire identifying 5 concepts and 48 components based on relevant scientific literature $[3,5-7,10,11,13,20,28-32]$ and our own experiences (supplemental Appendix A). To increase the participation of panel members, the purpose of the questionnaire, potential utility of the results, affected stakeholders, panel member confidentiality, and number of possible delphi rounds were described at the beginning of the questionnaire. Questionnaire items utilized a 10point Likert scale, on which panel members rated the importance of components from low importance (response of " 1 ") to very important (response of "10"). In addition to the concepts and components provided, we also asked panel members to propose additional concepts or components. 
Obtaining panel member responses in the first round took approximately 1 month. Three components had a mean rating less than or equal to 7 , which we considered to indicate a lack of panel member consensus; however, these components were retained in the second-round questionnaire. Also, 1 new concept and 3 new components were proposed by the panel members and were included in the second-round questionnaire, so we revised the descriptions of some components.

For the second delphi round, a new questionnaire identifying six concepts and fifty-one components was sent to the panel members (supplemental Appendix B). We described the changes made to the components based on the firstround results as well as the mean concept and component ratings in the first round at the beginning of the questionnaire. Ten of the eleven panel members participated in the second round, which took approximately two weeks. The three components that had a mean rating less than or equal to seven in the first round did not receive a mean rating greater than seven in the second round and, thus, were omitted. Also, one concept and two components proposed by the panel members in the first round did not receive a mean rating greater than seven in the second round and, thus, were omitted. Therefore, after two rounds of delphi, five concepts and forty-six components were included in the final model.

\section{RESULTS}

In the first delphi round, the highest-rated concept was excellence in performance, and the lowest-rated concept was excellence in education (Table 1). The highest-rated component was the role and influence of clinical information services on the level of care received by patients, and the lowest-rated component was clinical librarian availability even during non-office hours. At the end of the first round, the panel members reached consensus on 5 concepts and 45 components (i.e., mean rating 7 ).

In the second delphi round, the highest-rated concept was excellence in communication, and the lowest-rated concept was excellence in performance (Table 2). The highest-rated component was the mastery of search strategies in information resources and databases, and the lowest-rated component was the presence of clinical librarian feedback to influence the treatment process. At the end of the second round, the panel members reached consensus on all five concepts and forty-six components.

Table 1 First round of delphi panel member ratings

\begin{tabular}{|c|c|c|}
\hline Concept & Component & $\begin{array}{l}\text { Mean } \\
\text { rating }\end{array}$ \\
\hline \multirow[t]{8}{*}{ Education excellence (mean of 7.84) } & $\begin{array}{l}\text { 1. Converts health care professionals into practitioners of evidence- } \\
\text { based medicine (EBM) }\end{array}$ & 7.63 \\
\hline & $\begin{array}{l}\text { 2. Continues to educate health care professionals about clinical } \\
\text { information literacy }\end{array}$ & 8.36 \\
\hline & $\begin{array}{l}\text { 3. Continues to educate residents and interns about clinical } \\
\text { information literacy }\end{array}$ & 8.12 \\
\hline & $\begin{array}{l}\text { 4. Updates one's specialized knowledge and that of other librarians } \\
\text { by participating in continuing education }\end{array}$ & 9.09 \\
\hline & 5. Engages in practical in-service training in clinical librarianship & 8.54 \\
\hline & $\begin{array}{l}\text { 6. Recommends and updates medical librarianship curriculums } \\
\text { with a focus on clinical librarianship }\end{array}$ & 6.72 \\
\hline & 7. Trains a new generation of clinical librarians to support EBM & 7.00 \\
\hline & $\begin{array}{l}\text { 8. Takes advantage of the knowledge and expertise of leaders in } \\
\text { clinical librarianship }\end{array}$ & 7.45 \\
\hline \multirow[t]{2}{*}{ Performance excellence (mean of 8.27) } & $\begin{array}{l}\text { 9. Demonstrates relative command of terms and concepts used by } \\
\text { health care professionals }\end{array}$ & 8.27 \\
\hline & 10. Masters search strategies in information resources and databases & \\
\hline
\end{tabular}


Table 1 First round of delphi panel member ratings (continued)

\begin{tabular}{|c|c|c|c|}
\hline Concept & & Component & $\begin{array}{l}\text { Mean } \\
\text { rating }\end{array}$ \\
\hline \multirow{25}{*}{$\begin{array}{l}\text { Communication excellence (mean of } \\
7.91 \text { ) }\end{array}$} & & $\begin{array}{l}\text { Masters clinical question formation (e.g., problem, intervention, } \\
\text { comparison, outcome [PICO]) }\end{array}$ & 8.40 \\
\hline & 12. & $\begin{array}{l}\text { Demonstrates sufficient knowledge and mastery of evidence- } \\
\text { based information sources }\end{array}$ & 8.27 \\
\hline & 13. & $\begin{array}{l}\text { Pays attention to the clinical information needs of health care } \\
\text { professionals }\end{array}$ & 8.27 \\
\hline & 14. & $\begin{array}{l}\text { Provides reliable and up-to-date information (i.e., best evidence) } \\
\text { for health care professionals }\end{array}$ & 8.20 \\
\hline & 15. & Considers patient values in the EBM process & 7.80 \\
\hline & 16. & $\begin{array}{l}\text { Quickly and accurately responds to the clinical questions of } \\
\text { health care professionals }\end{array}$ & 8.18 \\
\hline & 17. & Supports accurate clinical decisions and records experiences & 7.63 \\
\hline & 18. & Attends clinical rounding & 8.00 \\
\hline & 19. & Maintains patient privacy & 8.63 \\
\hline & 20. & $\begin{array}{l}\text { Believes in the role and influence of clinical information services } \\
\text { on the level of care received by patients }\end{array}$ & 9.18 \\
\hline & 21. & Has a timely and effective presence in the clinical setting & 8.00 \\
\hline & 22. & $\begin{array}{l}\text { Appropriately and respectfully communicates with health care } \\
\text { professionals and patients }\end{array}$ & 8.36 \\
\hline & 23. & $\begin{array}{l}\text { Enjoys good self-esteem when interacting with health care } \\
\text { professionals }\end{array}$ & 8.36 \\
\hline & 24 . & Shows confidence in communicating with health care teams & 8.45 \\
\hline & 25. & Collaborates with health care teams to facilitate the EBM process & 9.00 \\
\hline & 26. & $\begin{array}{l}\text { Utilizes one's scientific ability and talent and that of other } \\
\text { librarians to provide appropriate services to health care } \\
\text { professionals }\end{array}$ & 7.90 \\
\hline & 27. & Actively interacts with and shows respect to other librarians & 7.81 \\
\hline & 28. & $\begin{array}{l}\text { Accepts constructive and wise feedback from other librarians } \\
\text { and health care professionals }\end{array}$ & 8.45 \\
\hline & 29. & Respects the job performance of other librarians & 7.90 \\
\hline & 30. & $\begin{array}{l}\text { Has insight into the information behavior and performance of } \\
\text { health care professionals }\end{array}$ & 7.54 \\
\hline & 31. & Avoids inappropriate jokes when performing job activities & 7.27 \\
\hline & 32. & Has a professional physical appearance in the workplace & 7.90 \\
\hline & 33. & $\begin{array}{l}\text { Effectively communicates with senior executives of the } \\
\text { organization to support and enhance EBM and clinical } \\
\text { librarianship }\end{array}$ & 8.18 \\
\hline & 34 . & $\begin{array}{l}\text { Gains the necessary communication skills for interacting with } \\
\text { others }\end{array}$ & 7.40 \\
\hline & 35. & Is available even during non-office hours when necessary & 5.60 \\
\hline
\end{tabular}


DOI: dx.doi.org/10.5195/jmla.2020.893

Table 1 First round of delphi panel member ratings (continued)

\begin{tabular}{|c|c|c|c|}
\hline Concept & & Component & $\begin{array}{l}\text { Mean } \\
\text { rating }\end{array}$ \\
\hline \multirow[t]{5}{*}{ Research excellence (mean of 8.13) } & 36. & Supports research related to clinical librarianship and EBM & 8.27 \\
\hline & 37. & $\begin{array}{l}\text { Supports rationale for using best evidence in clinical decision- } \\
\text { making }\end{array}$ & 8.63 \\
\hline & 38. & $\begin{array}{l}\text { Identifies clinical information needs of health care professionals } \\
\text { based on scientific research }\end{array}$ & 8.27 \\
\hline & 39. & $\begin{array}{l}\text { Develops scientific and teaching resources related to clinical } \\
\text { librarianship and EBM with an emphasis on new concepts, } \\
\text { theories, and local needs }\end{array}$ & 7.18 \\
\hline & 40 . & $\begin{array}{l}\text { Develops clinical librarian programs and services based on valid } \\
\text { research findings }\end{array}$ & 8.36 \\
\hline \multirow[t]{8}{*}{$\begin{array}{l}\text { Professional status excellence (mean of } \\
8.14 \text { ) }\end{array}$} & 41. & $\begin{array}{l}\text { Believes in the existential philosophy of clinical librarianship to } \\
\text { effectively enhance clinical information services provided to } \\
\text { health care professionals }\end{array}$ & 8.63 \\
\hline & 42. & $\begin{array}{l}\text { Believes in evidence-based clinical librarianship and its } \\
\text { formalization }\end{array}$ & 8.45 \\
\hline & 43. & $\begin{array}{l}\text { Gains the trust of health care professionals in the capabilities of } \\
\text { clinical librarians in the context of EBM }\end{array}$ & 7.63 \\
\hline & 44 . & $\begin{array}{l}\text { Strengthens and expands the independent and effective identity } \\
\text { of clinical librarians among the general public and health care } \\
\text { professionals }\end{array}$ & 8.00 \\
\hline & 45. & $\begin{array}{l}\text { Believes in professional cohesion and moving toward common } \\
\text { interests }\end{array}$ & 7.90 \\
\hline & 46. & $\begin{array}{l}\text { Strives to maximize the usefulness of clinical information } \\
\text { services }\end{array}$ & 8.27 \\
\hline & 47. & $\begin{array}{l}\text { Strives to promote the status of clinical librarians at national and } \\
\text { international levels }\end{array}$ & 8.27 \\
\hline & 48. & $\begin{array}{l}\text { Upgrades the level of professional integration of clinical } \\
\text { librarianship }\end{array}$ & 8.00 \\
\hline
\end{tabular}

Table 2 Second round of delphi panel member ratings

\begin{tabular}{|c|c|c|}
\hline Concept & Component & Mean \\
\hline \multirow[t]{6}{*}{ Education excellence (mean of 8.01) } & 1. Converts health care professionals into practitioners of EBM & 7.40 \\
\hline & $\begin{array}{l}\text { 2. Continues to educate health care professionals about clinical } \\
\text { information literacy }\end{array}$ & 8.10 \\
\hline & $\begin{array}{l}\text { 3. Continues to educate residents and interns about clinical } \\
\text { information literacy }\end{array}$ & 7.90 \\
\hline & $\begin{array}{l}\text { 4. Updates one's specialized knowledge and that of other librarians } \\
\text { by participating in continued education }\end{array}$ & 9.40 \\
\hline & 5. Engages in practical in-service training in clinical librarianship & 7.80 \\
\hline & $\begin{array}{l}\text { 6. Takes advantage of the knowledge and expertise of leaders in } \\
\text { clinical librarianship }\end{array}$ & 7.50 \\
\hline
\end{tabular}


Table 2 Second round of delphi panel member ratings (continued)

\begin{tabular}{|c|c|c|}
\hline Concept & Component & Mean \\
\hline \multirow[t]{14}{*}{ Performance excellence (mean of 7.98) } & $\begin{array}{l}\text { 7. Demonstrates relative command of the terms and concepts used } \\
\text { by health care professionals }\end{array}$ & 8.80 \\
\hline & 8. Masters search strategies in resources and databases & 9.60 \\
\hline & 9. Masters clinical question formation (e.g., PICO) & 9.20 \\
\hline & $\begin{array}{l}\text { 10. Demonstrates sufficient knowledge and mastery of evidence- } \\
\text { based information sources }\end{array}$ & 9.20 \\
\hline & $\begin{array}{l}\text { 11. Pays attention to the clinical information needs of health care } \\
\text { professionals }\end{array}$ & 8.90 \\
\hline & $\begin{array}{l}\text { 12. Provides reliable and up-to-date information (i.e., best evidence) } \\
\text { for health care professionals }\end{array}$ & 9.30 \\
\hline & 13. Considers patient values in EBM process & 8.33 \\
\hline & $\begin{array}{l}\text { 14. Quickly and accurately responds to the clinical questions from } \\
\text { health care professionals }\end{array}$ & 9.20 \\
\hline & 15. Supports accurate clinical decisions and records experiences & 7.80 \\
\hline & 16. Attends clinical rounding & 8.60 \\
\hline & 17. Maintains patient privacy & 8.80 \\
\hline & $\begin{array}{l}\text { 18. Believes in the role and influence of clinical information services } \\
\text { on the level of care the patient receives }\end{array}$ & 9.00 \\
\hline & 19. Has a timely and effective presence in the clinical setting & 8.50 \\
\hline & 20. Provides feedback to influence the treatment process & 8.80 \\
\hline \multirow[t]{13}{*}{$\begin{array}{l}\text { Communication excellence (mean of } \\
8.55)\end{array}$} & $\begin{array}{l}\text { 21. Appropriately and respectfully communicates with health care } \\
\text { professionals and patients }\end{array}$ & 8.80 \\
\hline & $\begin{array}{l}\text { 22. Enjoys good self-esteem when interacting with health care } \\
\text { professionals }\end{array}$ & 9.20 \\
\hline & 23. Shows confidence in communicating with health care teams & 9.12 \\
\hline & 24. Collaborates with health care teams to facilitate the EBM process & 9.00 \\
\hline & $\begin{array}{l}\text { 25. Utilizes one's scientific ability and talent and that of other } \\
\text { librarians to provide appropriate services to health care } \\
\text { professionals }\end{array}$ & 8.30 \\
\hline & 26. Actively interacts with and shows respect to other librarians & 8.70 \\
\hline & $\begin{array}{l}\text { 27. Accepts constructive and wise feedback from other librarians and } \\
\text { health care professionals }\end{array}$ & 8.80 \\
\hline & 28. Respects the job performance of other librarians & 8.50 \\
\hline & $\begin{array}{l}\text { 29. Has insight into the information behavior and performance of } \\
\text { health care professionals }\end{array}$ & 8.11 \\
\hline & 30. Avoids inappropriate jokes when performing job activities & 7.60 \\
\hline & 31. Has a professional physical appearance in the workplace & 8.60 \\
\hline & $\begin{array}{l}\text { 32. Effectively communicates with senior executives of the } \\
\text { organization to support and enhance EBM and clinical } \\
\text { librarianship }\end{array}$ & 8.50 \\
\hline & $\begin{array}{l}\text { 33. Gains the necessary communication skills for interacting with } \\
\text { others }\end{array}$ & 8.10 \\
\hline
\end{tabular}


DOI: dx.doi.org/10.5195/jmla.2020.893

Table 2 Second round of delphi panel member ratings (continued)

\begin{tabular}{|c|c|c|}
\hline Concept & Component & Mean \\
\hline \multirow[t]{5}{*}{ Research excellence (mean of 8.04) } & 34. Supports research related to clinical librarianship and EBM & 7.90 \\
\hline & $\begin{array}{l}\text { 35. Supports rationale for using best evidence in clinical decision- } \\
\text { making }\end{array}$ & 8.20 \\
\hline & $\begin{array}{l}\text { 36. Identifies clinical information needs of health care professionals } \\
\text { based on scientific research }\end{array}$ & 8.55 \\
\hline & $\begin{array}{l}\text { 37. Develops scientific and teaching resources related to clinical } \\
\text { librarianship and EBM with an emphasis on new concepts, } \\
\text { theories, and local needs }\end{array}$ & 7.40 \\
\hline & $\begin{array}{l}\text { 38. Develops clinical librarian programs and services based on valid } \\
\text { research findings }\end{array}$ & 8.20 \\
\hline \multirow[t]{8}{*}{$\begin{array}{l}\text { Professional status excellence (mean of } \\
8.45 \text { ) }\end{array}$} & $\begin{array}{l}\text { 39. Believes in the existential philosophy of clinical librarianship to } \\
\text { effectively enhance clinical information services provided to } \\
\text { health care professionals }\end{array}$ & 8.40 \\
\hline & $\begin{array}{l}\text { 40. Believes in evidence-based clinical librarianship and its } \\
\text { formalization }\end{array}$ & 8.60 \\
\hline & $\begin{array}{l}\text { 41. Gains the trust of health care professionals in the capabilities of } \\
\text { clinical librarians in the context of EBM }\end{array}$ & 8.40 \\
\hline & $\begin{array}{l}\text { 42. Strengthens and expands the independent and effective identity } \\
\text { of clinical librarians among the general public and health care } \\
\text { professionals }\end{array}$ & 8.40 \\
\hline & $\begin{array}{l}\text { 43. Believes in professional cohesion and moving toward common } \\
\text { interests }\end{array}$ & 8.30 \\
\hline & 44. Strives to maximize the usefulness of clinical information services & 8.77 \\
\hline & $\begin{array}{l}\text { 45. Strives to promote the status of clinical librarians at national and } \\
\text { international level }\end{array}$ & 8.50 \\
\hline & $\begin{array}{l}\text { 46. Upgrades the level of professional integration of clinical } \\
\text { librarianship }\end{array}$ & 8.33 \\
\hline
\end{tabular}

\section{DISCUSSION}

Based on the results obtained in the second delphi round, five concepts and forty-six components were identified and confirmed in order to develop a model of professional ethics excellence for clinical librarians. The highest-rated concept was communication excellence, and the lowest-rated concept was performance excellence. The highestrated component was mastering search strategies in information resources and databases, and the lowest-rated component was the presence of clinical librarian feedback to influence the treatment process.

\section{Education excellence}

Clinical librarians should update their specialized knowledge and that of their librarian colleagues by attending continuing education courses aimed at helping them improve clinical information literacy among health care professionals and provide context for using reliable information resources and databases in the practice of EBM. Previous studies have addressed these educational issues and emphasize that clinical librarians should effectively teach information literacy concepts in the EBM process [33,34], because high-quality implementation of EBM in clinical centers depends on the training of both clinical librarians and physicians [10, 35]. Given the speed of production and dissemination of information resources, being up to date is a prerequisite for dynamically providing high-quality health care [20] and requires specific training. Furthermore, it is important that managers of health sciences libraries receive continuing education to update their knowledge about ethical issues [21]. 


\section{Performance excellence}

EBM is a systematic and purposeful activity, each step of which should be promoted by clinical librarians working together with health care professionals [35]. Clinical librarians can play an important role in the EBM process, as their presence can serve to meet physicians' information needs and consequently improve the quality of care that is provided to patients [36]. Because the practice of EBM requires specialized knowledge and expertise, clinical librarians should be familiar with medical terminology, master the development of search strategies to find credible evidence, critically evaluate articles, have sufficient motivation to participate in medical teams, support accurate clinical decision-making, and be able to meet the clinical information needs of health care professionals in the shortest possible time [9-11, 20, 28, 34, 37]. Also, several studies emphasize the need not only to provide the best evidence to health care professionals and patients, but also to protect their privacy and confidentiality $[3,6,7,20]$.

\section{Communication excellence}

Clinical librarians should strive to improve the quality of their communication with librarian colleagues and health care professionals by ensuring that their communication is constructive, useful, and respectful. At the same time, clinical librarians should welcome constructive criticism that they receive from colleagues and health care professionals, thereby bolstering the bidirectional nature of communication. Several previous studies have pointed to these issues and emphasize that clinical librarians should engage in appropriate and constructive communication with their colleagues, health care professionals, and patients [6, 20,34]. This could be achieved in part by acquiring specialized knowledge about professional relationships and communication skills.

\section{Research excellence}

The field of clinical librarianship must make use of validated research to improve the quality of its processes. To accomplish this, educational departments and research centers at universities should support EBM and clinical librarianship research to understand and meet the clinical information needs of health care professionals and to develop educational and research resources related to clinical librarianship and EBM with an emphasis on new concepts, theories, and local needs. Today's clinical librarians must base their activities and decisions on credible research and evidence. According to many studies, clinical librarians should not only present accurate and reliable evidence to physicians $[7,9,10,33-35,37$, 38], but they should also be involved in making evidence-based decisions by collecting, analyzing, and applying up-to-date research to their job processes. In addition, clinical librarians should position themselves to help physicians publish their research results.

\section{Professional status excellence}

Professionals achieve success when their stakeholders benefit from their services. In other words, professional status is meaningless without contributions to others [39]. Clinical librarians should recognize that their primary beneficiaries are health care professionals and that their secondary beneficiaries are patients. Therefore, every effort to make accurate evidence available to health care professionals will ultimately lead to better care of patients. To achieve this goal, improving the quality of services, maintaining professional coherence, and establishing clinical librarians in health centers as well as striving to win the trust of health care professionals in the EBM-related capabilities of clinical librarians are of great importance. Thus, it is necessary to develop a philosophy, ideals, specialized knowledge, and professional standards for clinical librarians $[6,7,20]$.

\section{Limitations}

This study has some limitations. Although we attempted to identify experts to participate on the delphi panel, we may have failed to contact some key experts in clinical librarianship, which may have partially affected the results. Also, the lack of information related to the professional ethics of clinical librarians made it difficult to compile various sections of the questionnaire.

\section{CONCLUSION}

Developing and promoting principles of professional ethics for clinical librarians can help the health care system balance the interests of all stakeholders, including clinical librarians, health care professionals, and patients. In the present 
study, we used a literature review and delphi panel to identify and approve five concepts and forty-six components of excellence in education, performance, communication, research, and professional status for clinical librarians. Our finding that the highest-rated concept was excellence in communication confirms the importance of communication in professional ethics. Also, the highest-rated component was mastery of search strategies in information resources and databases, suggesting that clinical librarians with more skills in finding information that physicians need are more successful in providing credible evidence to physicians and engender greater physician confidence in the profession of clinical librarianship.

Overall, identifying and striving to implement principles of professional ethics excellence for clinical librarians can enhance the professionalization of clinical librarians and result in better information services for physicians. Furthermore, incorporating these principles into the curriculum for health sciences library and information sciences students or into workshops for active clinical librarians can further formalize the profession and practice of EBM.

\section{DATA AVAILABILITY STATEMENT}

The de-identified dataset and supporting files are available in Figshare at

https://figshare.com/articles/Copy_of_round_1_4 $\underline{\mathrm{xlsx} / 12091155}$.

\section{ACKNOWLEDGMENT}

We appreciate the delphi panel members for kindly taking their valuable time to participate in this research.

\section{REFERENCES}

1. Davis M. Code making: how software engineering became a profession. Chicago, IL: Center for the Study of Ethics in the Professions, Illinois Institute of Technology; 2009.

2. Kluge EH, Lacroix P, Ruotsalainen P. Ethics certification of health information professionals. Yearb Med Inform. 2018 Aug;27(1):37-40. DOI: http://dx.doi.org/10.1055/s-0038$\underline{1641196}$

3. Hurych JM, Glenn AC. Ethics in health sciences librarianship. Bull Med Libr Assoc. 1987 Oct;75(4):342-8.

4. Dole WV, Hurych, JM. Values for librarians in the Information Age. J Inf Ethics. 2001 Fall;10(2):38-50.
5. International Federation of Library Associations and Institutions (IFLA). IFLA code of ethics for librarians and other information workers (full version) [Internet]. The Hague: The Federation; 2012 [cited 16 Jan 2018]. <https://www.ifla.org/publications/node/11092>.

6. Medical Library Association. Code of ethics for health sciences librarianship [Internet]. Chicago, IL: The Association; 2010 [cited 5 Apr 2020]. <https://www.mlanet.org/page/code-of-ethics>.

7. Medical Library Association. Competencies for professional success: health sciences librarianship in context [Internet]. Chicago, IL: The Association; 2007 [cited 6 Jun 2019]. $<$ https://www.mlanet.org/page/competencies-forprofessional-success-health-sciences-librarianship-in-context>.

8. Harrison J, Beraquet V. Clinical librarians, a new tribe in the UK: roles and responsibilities. Health Inf Libr J. 2010 Jun;27(2):123-32. DOI: http://dx.doi.org/10.1111/j.14711842.2009.00862.x.

9. Motamedi F, AleTaha A, Bahaadini K. The clinical librarians and information professionals' role in telemedicine: assisting the general practitioners working in rural areas of Kerman Province in the treatment process. J Health Manag Inform. 2014 Apr;1(2):31-5.

10. Movahedi F, Ashrafi-rizi H, Sharifmoghadam H. Physicians' perception about the role of clinical librarianship at Alzahra Medical Center. J Health Admin. 2014;16(54):71-81. (In Persian).

11. Roper T. The impact of the clinical librarian: a review. J Eur Assoc Health Inf Libr. 2015;11(4):19-22.

12. Ashrafi-rizi H, Zarmehr F. Criticism of health researches: why and how. J Health Manag Inform. 2016 Apr;3(2):64-5.

13. Kazempour $Z$, Ashrafi-rizi $H$, Taheri $B$. The attention rate of librarians in Isfahan University of Medical Sciences and Isfahan University to professional ethics based on ethical codes of Iranian university librarians. Health Inf Manag. 2012 Jan-Feb;8(6):795-806. (In Persian).

14. Rezaei M, Shabani A, Siadat SA, Naderi Kharaji F. Compliance with organizational professional codes of ethics by the Iran Public Libraries Foundation staff in Yazd Province. Res Inf Sci Pub Libr. 2013;19(1):5-20. (In Persian).

15. Zandian F, Latifi M, Siamian H. Central Libraries librarians point of view of the public universities in relation to draft code of professional ethics of Iranian librarians and information specialists and offering a framework for final code. Q J Knowl Studies. 2009;1(3):71-85. (In Persian).

16. Kendrick KD, Leaver E. Impact of the code of ethics on workplace behavior in academic libraries. J Inf Ethics. 2011 Apr;20(1):86-112.

17. Esfandiyari Moghadam A, Hassanloo S. Point of view of the Association of Iranian Library and Information Sciences members to professional ethics principles of librarianship. J Ethics Sci Technol. 2010;5(1):48-56. (In Persian).

18. Ghaffari S, Zakiani S. Compliance with professional ethics in librarians of Central Library and Documentation Center of Tehran University. J Bioethics. 2017 Fall;7(25):7-15. (In Persian).

19. Kokabi M. Where is information ethics in Iranian library and information science publications and services? Electron J Inf Syst Eval. 2009 Jan;12(1): 89-94. 
20. Byrd GD, Devine PJ, Corcoran KE. Health sciences librarians' awareness and assessment of the Medical Library Association code of ethics for health sciences librarianship: the results of a membership survey. J Med Libr Assoc. 2014 Oct;102(4):257-70. DOI: http://dx.doi.org/10.3163/1536-5050.102.4.007.

21. Tooey MJ, Arnold GN. The impact of institutional ethics on academic health sciences library leadership: a survey of academic health sciences library directors. J Med Libr Assoc. 2014 Oct;102(4):241-6. DOI: http://dx.doi.org/10.3163/1536-5050.102.4.005.

22. American Library Association (ALA). Code of ethics of the American Library Association [Internet]. Chicago, IL: The Association; 2008 [cited 1 Jan 2018]. <http://www.ala.org/advocacy/sites/ala.org.advocacy/file s/content/proethics/codeofethics/Code $\% 20$ of $\% 20$ Ethics $\% 20$ of $\% 20$ the $\% 20$ American $\% 20$ Library $\% 20$ Association.pdf>.

23. Board of the Association of Hungarian Librarians, Board of the Federation of Libraries and Information Centres. Professional code of ethics of Hungarian librarians [Internet]. Budapest, Hungary: The Association; 2006 [cited 16 Jan 2018]. <https://www.ifla.org/files/assets/faife/codesofethics/hun gary.pdf>.

24. Hong Kong Library Association (HKLA). Hong Kong Library Association code of ethics [Internet]. Hong Kong: The Association; 2005 [cited 23 Jan 2018]. <https://hkla.org/about-us/code-of-ethics/>.

25. Feizi K, Irandost M. Delphi study. Tehran, Iran: Industrial Management Organization; 2013. (In Persian).

26. Akins RB, Tolson H, Cole BR. Stability of response characteristics of a delphi panel: application of bootstrap data expansion. BMC Med Res Methodol. 2005;5(1):37. DOI: http://dx.doi.org/10.1186/1471-2288-5-37.

27. Powell RR, Connaway LS. Basic research methods for librarians. 4th ed. Englewood, CO: Libraries Unlimited; 2004.

28. Cuddy TM. Value of hospital libraries: the Fuld Campus study. J Med Libr Assoc. 2005 Oct;93(4):446-9.

29. MacDonald SL, Winter T, Luke R. Roles for Information professionals in patient education: librarians' perspective. Partnersh Can J Libr Inf Pract Res. 2010 Jul;5(1):1-15. DOI: http://dx.doi.org/10.21083/partnership.v5i1.1153.

30. Marshall JG. Measuring the value and impact of health library and information services: past reflections, future possibilities. Health Inf Libr J. 2007 Dec;24(1):4-17.

31. Washington L. Enabling consumer and patient engagement with health information. J AHIMA. 2014 Feb;85(2):56-9.

32. Zahedi R, Zahedi F. Patients' and healthcare clients' rights in professional codes of ethics of library and information sciences. Iranian J Ethics Med History. 2012;5(5):53-65. (In Persian).

33. Kazempour $Z$, Ashrafi-rizi H. Clinical information intelligence: a new concept in the field of evidence-based medicine (EBM). Depiction Health. 2018;9(1):1-4. (In Persian).

34. Mirzaei K, Zahmatkesh S. Teaching evidence-based medicine and its impact on knowledge, attitudes and skills of clinical students of Bushehr University of Medical Sciences. J Med Educ Dev. 2013;8(3):13-22. (In Persian).
35. Kalavani A, Kazerani M, Shekofteh M. Evaluation of SBMU residents' knowledge and use of evidence-based medical databases and concepts. J Payavard Salamat. 2018;12(1):3443. (In Persian).

36. Soleimanzadeh-Najafi NS, Zare-Farashbandi E, Moradi R, Zare-Farashbandi F. Familiarity of medical librarianship students and librarians with the duties of a clinical librarian. Health Inf Manag. 2017;14(4):181-5. (In Persian).

37. Kahouei M, Eskrootchi R, Ebadi FAF, Abolhassani H. Medical students caring information needs and seeking behavior pattern in clinical education of an emergency department. Health Inf Manag. 2011;7(4):389-99. (In Persian).

38. Kostagiolas PA, Zimeras S. Enhancement of hospital libraries and information services through an e-support system for lifelong learning quality methodologies and tools. Int J Educ Inform Technol. 2008;2(2):132-7.

39. Dayani MH. The principles of reference services in libraries and information centers. Mashhad, Iran: Ketabkhane Rayenehei; 2008. (In Persian).

\section{SUPPLEMENTAL FILES}

- Appendix A: Delphi first-round questionnaire (translation)

- Appendix B: Delphi second-round questionnaire (translation)

\section{AUTHORS' AFFILIATIONS}

Hasan Ashrafi-rizi, hassanashrafi@mng.mui.ac.ir, https://orcid.org/00000001-6052-2087, Professor, Health Information Technology Research Center, Isfahan University of Medical Sciences, Isfahan, Iran

Zahra Kazempour, zahrakazempour00@gmail.com, https://orcid.org/0000-0001-6834-2814, Assistant Professor, Library and Information Science, Department of Knowledge and Information Science, Payame Noor University, Tehran, Iran

Fatemeh Sheikhshoaei (corresponding author), fashoaei@sina.tums.ac.ir, https://orcid.org/0000-0001-8804-5403, Assistant Professor, Medical Library and Information Sciences, School of Allied Medicine, Tehran University of Medical Sciences, Tehran, Iran

Zahra Ghazavi, MSc, ghazaviz@ymail.com, Iran University of Medical Sciences, Tehran, Iran

Received November 2019; accepted April 2020

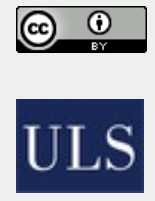

Articles in this journal are licensed under a Creative Commons Attribution 4.0 International License.

This journal is published by the University Library System of the University of Pittsburgh as part of its D-Scribe Digital Publishing Program and is cosponsored by the University of Pittsburgh Press.

ISSN 1558-9439 (Online) 